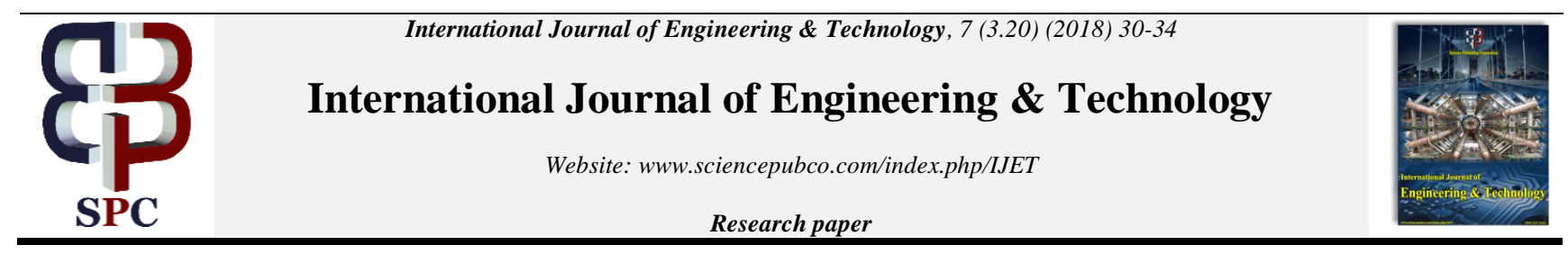

\title{
A Review on Prevalence and Risk Factors of Musculoskeletal Disorders (Msds) Among VDT Users
}

\author{
Siti Shafika Mohamad and Mohd Nasrull Abdol Rahman \\ Department of Manufacturing and Industrial Engineering, \\ Faculty of Mechanical and Manufacturing Engineering, \\ Universiti Tun Hussein Onn Malaysia (UTHM), \\ 86400 Batu Pahat, Johor, Malaysia
}

\begin{abstract}
This review aims to to identify the prevalence of computer work related to musculoskeletal disorders among Video Display Terminal users. The association between risk factors and musculoskeletal disorders was also identified. Data from 1990 until 2015 was retrieved using electronic databases. The review was done based on computer work, office risk factors, musculoskeletal disorders, working posture, office components and office environment. Epidemiology studies show that physical exposure has a moderate and to strong association with Computer Work-Related Musculoskeletal Disorders. Sixteen risk factors for office workstation swith significant as sociations with body part exposure outcomeswere identified. Through the studies, it was found that computer-related risk factors correspond with Musculoskeletal Disorders (MSDs) including awkward postures, long duration of computer use, work involving repetitive processes and the office environment
\end{abstract}

Keywords: ergonomic risk factors; computer work; musculoskeletal disorders; office workstation

\section{Introduction}

Ergonomic Risk Factors (ERFs) are considered as the main source of occupational injuries among workers.

[1,2]. Injuries often caused by ERFs are Musculoskeletal Disorders, Cumulative Trauma Disorders (CTDs), Upper Limb Disorder (ULDs) and Repetitive Strain Injury (RSI) [3, 4]. Office work or Visual Display Terminal(VDT) work poses a high risk of musculoskeletal disorders (MSDs) [5, 6].Computer users with long duration of computer use experienced more muscuosleteal symptoms compared to those whose used computer for a short duration [7,8]. Futhermore, in the review of VDT studies stated, VDT work indicated high prevalence of disorders in the neck, upper extremities and lower back of the body compared with non VDT-work [7-10]. Among the risk factors associated with MSDs are maintaining a static sitting posture for a long time and awkward postures of the head, neck and upper limb, wrist and forearm and repetitive movement of the fingers [11- 13]. In addition, problems associatied with the eyes could also occur due to constant use of computer such as eye strain, blurriness, dryness and difficulty in focusing $[14,15]$. Thus, this paper aims to identify the prevalence of computer work related to musculoskeletal disorders among VDT users. Besides that, the association between risk factors and musculoskeletal was also identified.

\section{Methods}

\subsection{Selection of Literature from the Database}

The selection of literature was conducted usingelectronic databases and publications. The databases included ScienceDirect, Scopus, Malaysian Standard, British Standard, Google and Google scholar. The searches covered material from 1990 until 2015. The searches used a combination of terms related to observational methods for computer work using "OR" and "AND". The terms or keywords used were: methods based on computer work, office risk factors and musculoskeletal disorders, working posture, office components(chair, desk, keyboard, mouse, monitor, telephone, document holder, and wrist rest), office environment (lighting, noise, temperature, awkward posture, repetition, and force. Exactly 115 journal articles and review reports were screened by M.S.S. and R.M.N.A as shown in Figure 1. 


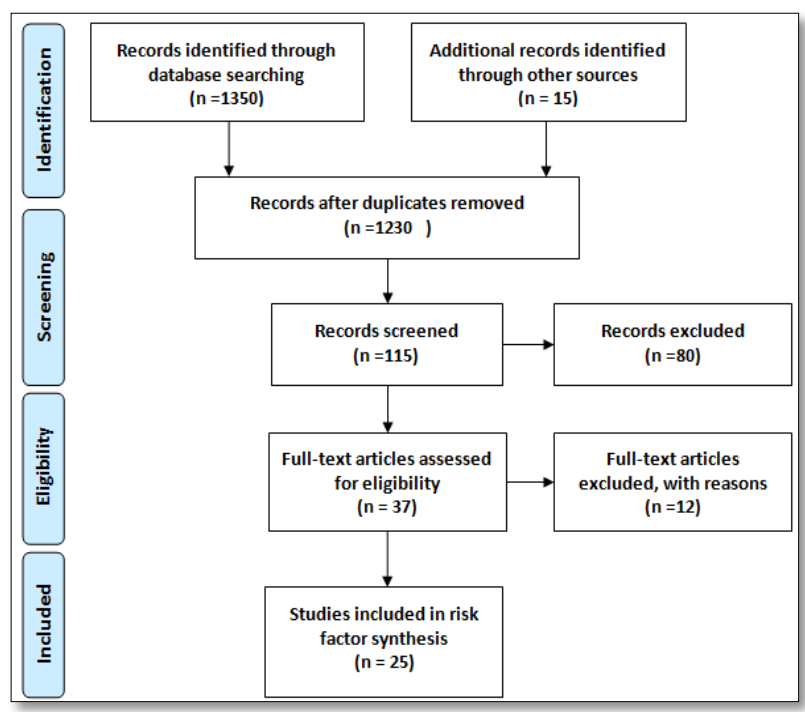

Figure 1Flow diagram of study selection process

\subsection{Developing the Evaluation Criteria}

The evaluation criteria for these review methods were developed by the researchers. The inclusion criteria used for this research included sample population such as computer users, office workers and customer service officers. Besides that, the exposure and outcoms of risk factors related to office workstations (physical factors, office components, and office environments) were identified.

\subsection{Assessment of Level of Evidence and Strength of Association}

The categorization for strength of association was done according to a method used by Hemingway \& Marmot and Hartvigsenet al., $[16,17]$. Three categories of strength include low significant positive association with $(\mathrm{p}>0.05)$ or Odd Ratio $(\mathrm{OR}<1.00)$ or $95 \%$ of Confidence Interval $(95 \%$ CI $\leq 1.00)$, moderate association $\quad(1.01<\mathrm{OR}<2.00$ or $0.01<\mathrm{p}<0.05)$ and strong association where OR $>2.00$ or $(\mathrm{p}<0.01)$.

\section{Results and Discussions}

Table 1 shows the the summary of 10 studies of risk factors for computer work-related musculoskeletal disorders. These studies evaluate the relationship between computer use and symptoms of Work-related Musculoskeletal Disorders (WMSDs). Most of the studies are cross-sectional and longitudinal studies. The studies have been conducted on industrial populations. Workplace factors were frequently assessed via questionnaires, job sampling methods, video analyses, or measurement of work posture and workstations to characterize exposure related to computer work use. The table showed the outcomesofOdd Ratio (OR)and 95\% Confidence Interval (CI).

From the review, the risk factors for office workstations were divided into two domains and sixteen items were identified as shown in Figure 2and Table 2. About 67 documents fit the criteria and about 15 papers were potential reference materials based on the guidelines. The domains identified consist of office components (body part, repetition, and force) and office environments

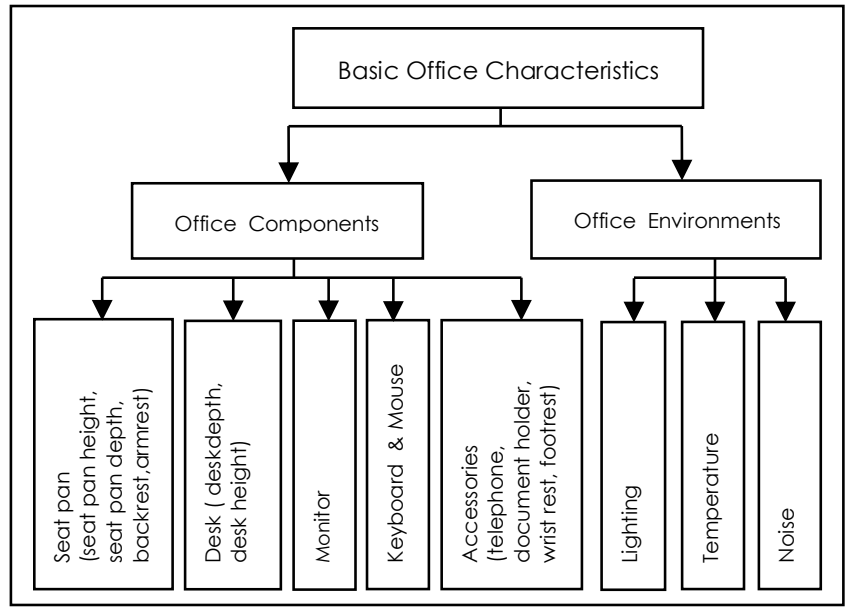

Figure 2 Characteristics of office components and nvironment

Table 1 Summary of 10 studies on risk factors for computer work-related MSDs.

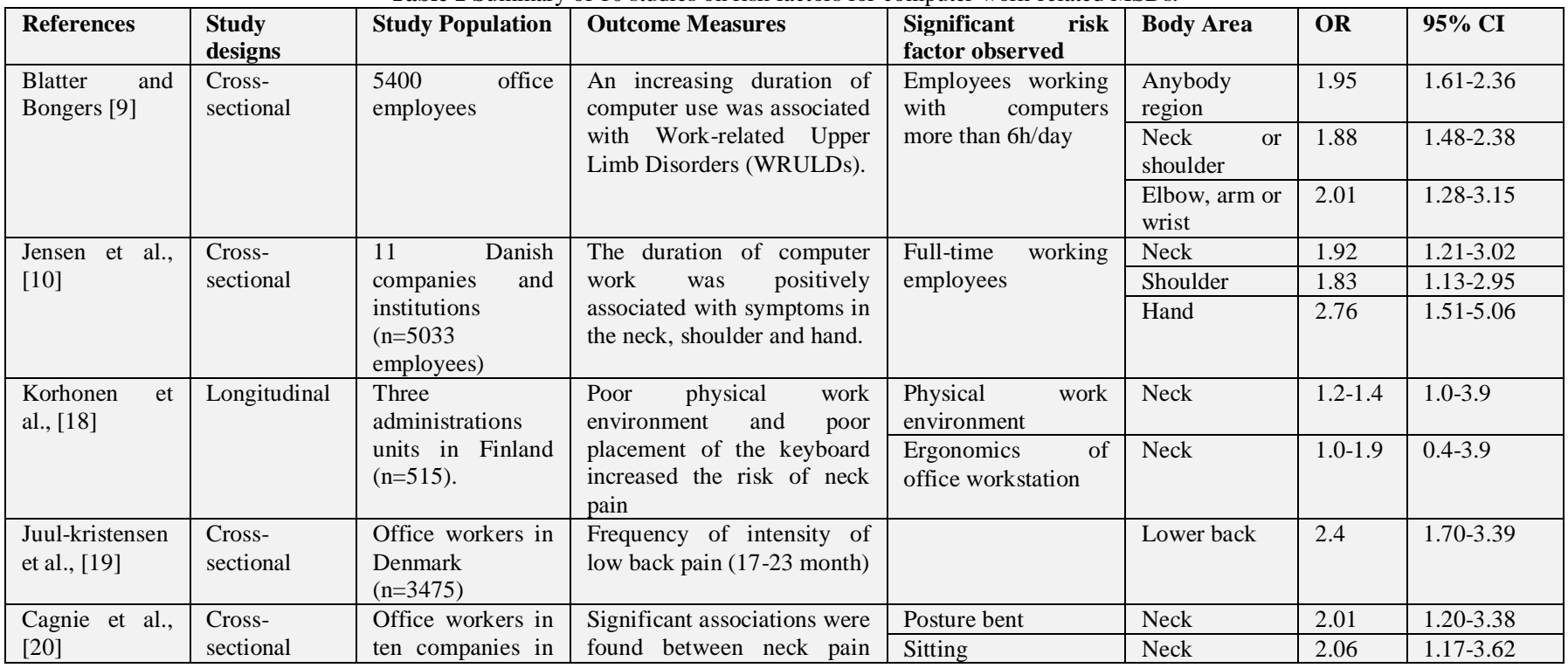




\begin{tabular}{|c|c|c|c|c|c|c|c|}
\hline & & Belgium $\mathrm{N}=720$ & and often holding the neck & $\begin{array}{l}\text { Same movement/ } \\
\text { min }\end{array}$ & Neck & 1.68 & $1.02-2.76$ \\
\hline \multirow{6}{*}{$\begin{array}{l}\text { N.Turhan. et } \\
\text { al., [21] }\end{array}$} & \multirow[t]{6}{*}{ Longitudinal } & \multirow{6}{*}{$\begin{array}{l}\mathrm{N}=173 \text { operators } \\
(14 \text { males and } 159 \\
\text { females) }\end{array}$} & \multirow{6}{*}{$\begin{array}{l}\text { Thirty six percent of workers } \\
\text { had chronic pain in at least } \\
\text { one region of the upper } \\
\text { body. }\end{array}$} & \multirow{6}{*}{$\begin{array}{l}\text { Workstation and } \\
\text { workload }\end{array}$} & Fingers & 3.40 & $1.05-10.99$ \\
\hline & & & & & Wrist & 1.47 & $1.11-1.96$ \\
\hline & & & & & Forearm & 1.90 & $1.20-3.04$ \\
\hline & & & & & Elbows & 5.81 & $1.61-20.94$ \\
\hline & & & & & Shoulders & 5.44 & $1.46-20.28$ \\
\hline & & & & & Neck & 18.4 & $2.18-151.8$ \\
\hline \multirow[t]{3}{*}{$\begin{array}{l}\text { Lapointe et al., } \\
\text { [22] }\end{array}$} & \multirow[t]{3}{*}{$\begin{array}{l}\text { Cross- } \\
\text { sectional }\end{array}$} & \multirow{3}{*}{$\begin{array}{l}\text { White-collar } \\
\text { workers at } 3 \text { large } \\
\text { public services } \\
\text { organizations in } \\
\text { Quebec City, } \\
\text { Canada }(n=2431)\end{array}$} & \multirow[t]{3}{*}{$\begin{array}{l}\text { 6-month incidence of lower } \\
\text { back symptoms }\end{array}$} & $\begin{array}{l}\text { Low postural risk } \\
\text { factors and high job } \\
\text { strain }\end{array}$ & lower back & 2.53 & $1.09-5.85$ \\
\hline & & & & $\begin{array}{l}\text { High postural risk } \\
\text { factors and low job } \\
\text { strain }\end{array}$ & lower back & 2.51 & $1.23-5.09$ \\
\hline & & & & $\begin{array}{l}\text { High postural risk } \\
\text { factors and high job } \\
\text { strain }\end{array}$ & lower back & 5.51 & $2.33-13.03$ \\
\hline \multirow{2}{*}{$\begin{array}{l}\text { Angelo } \\
\text { d'Ericco et al., } \\
{[23]}\end{array}$} & \multirow[t]{2}{*}{$\begin{array}{l}\text { Cross- } \\
\text { sectional }\end{array}$} & \multirow{2}{*}{$\begin{array}{l}\text { Seven call centers } \\
\text { in Turin area } \\
(\mathrm{n}=775 \text { workers })\end{array}$} & \multirow{2}{*}{$\begin{array}{l}\text { High prevalence of upper } \\
\text { limb } \quad \text { musculoskeletal } \\
\text { symptoms }\end{array}$} & \multirow[t]{2}{*}{$\begin{array}{l}\text { Full time call center } \\
\text { worker }\end{array}$} & $\begin{array}{l}\text { Neck and } \\
\text { Shoulder }\end{array}$ & $\begin{array}{l}1.25- \\
1.83\end{array}$ & $0.98-2.16$ \\
\hline & & & & & $\begin{array}{l}\text { Elbow } \\
\text { Hand/wrist }\end{array}$ & $\begin{array}{l}1.34- \\
2.99\end{array}$ & $0.73-7.79$ \\
\hline \multirow[t]{8}{*}{ Cho et al., [24] } & \multirow[t]{8}{*}{ Longitudinal } & \multirow{8}{*}{$\begin{array}{lr}3 & \text { companies and } \\
1 & \text { university } \\
(\mathrm{n}=254 \text { subjects })\end{array}$} & \multirow{8}{*}{$\begin{array}{l}\text { High psychological distress } \\
\text { with shoulder and upper } \\
\text { back pain, whereas high } \\
\text { workload was associated } \\
\text { with lower back. }\end{array}$} & \multirow{4}{*}{$\begin{array}{l}\text { Psychological } \\
\text { distress }\end{array}$} & Shoulder & 3.46 & $1.38-8.64$ \\
\hline & & & & & Neck & 2.08 & $0.94-4.63$ \\
\hline & & & & & Upper back & 2.24 & $1.15-4.74$ \\
\hline & & & & & Lower back & 1.47 & $0.77-2.78$ \\
\hline & & & & \multirow[t]{4}{*}{ Workload } & Shoulder & 1.70 & $0.91-3.18$ \\
\hline & & & & & Neck & 1.55 & $0.84-2.88$ \\
\hline & & & & & Upper back & 1.61 & $0.91-2.84$ \\
\hline & & & & & Lower back & 1.89 & $1.07-3.36$ \\
\hline \multirow{3}{*}{$\begin{array}{l}\text { Hanvold et al., } \\
\text { [25] }\end{array}$} & \multirow[t]{3}{*}{ Longitudinal } & \multirow{3}{*}{$\begin{array}{l}135 \text { media/ } \\
\text { Design students } \\
167 \quad \text { students } \\
\text { hairdressers, } 118 \\
\text { student } \\
\text { electricians, }\end{array}$} & \multirow{3}{*}{$\begin{array}{l}\text { Neck and shoulder pain } \\
\text { among young adults entering } \\
\text { working life increase the } \\
\text { tendency towards moderate } \\
\text { /severe pain levels }\end{array}$} & Whole group & \multirow{3}{*}{$\begin{array}{l}\text { Neck and } \\
\text { Shoulder }\end{array}$} & 1.02 & $1.01-1.03$ \\
\hline & & & & $\begin{array}{ll}\begin{array}{l}\text { Media/ design } \\
\text { students }\end{array} & \\
\end{array}$ & & 1.01 & $1.00-1.02$ \\
\hline & & & & $\begin{array}{l}\text { Electrician/ } \\
\text { hairdressers students }\end{array}$ & & 1.02 & $1.01-1.03$ \\
\hline
\end{tabular}

Table 2 Summary of Risk Factors of Office Workstations

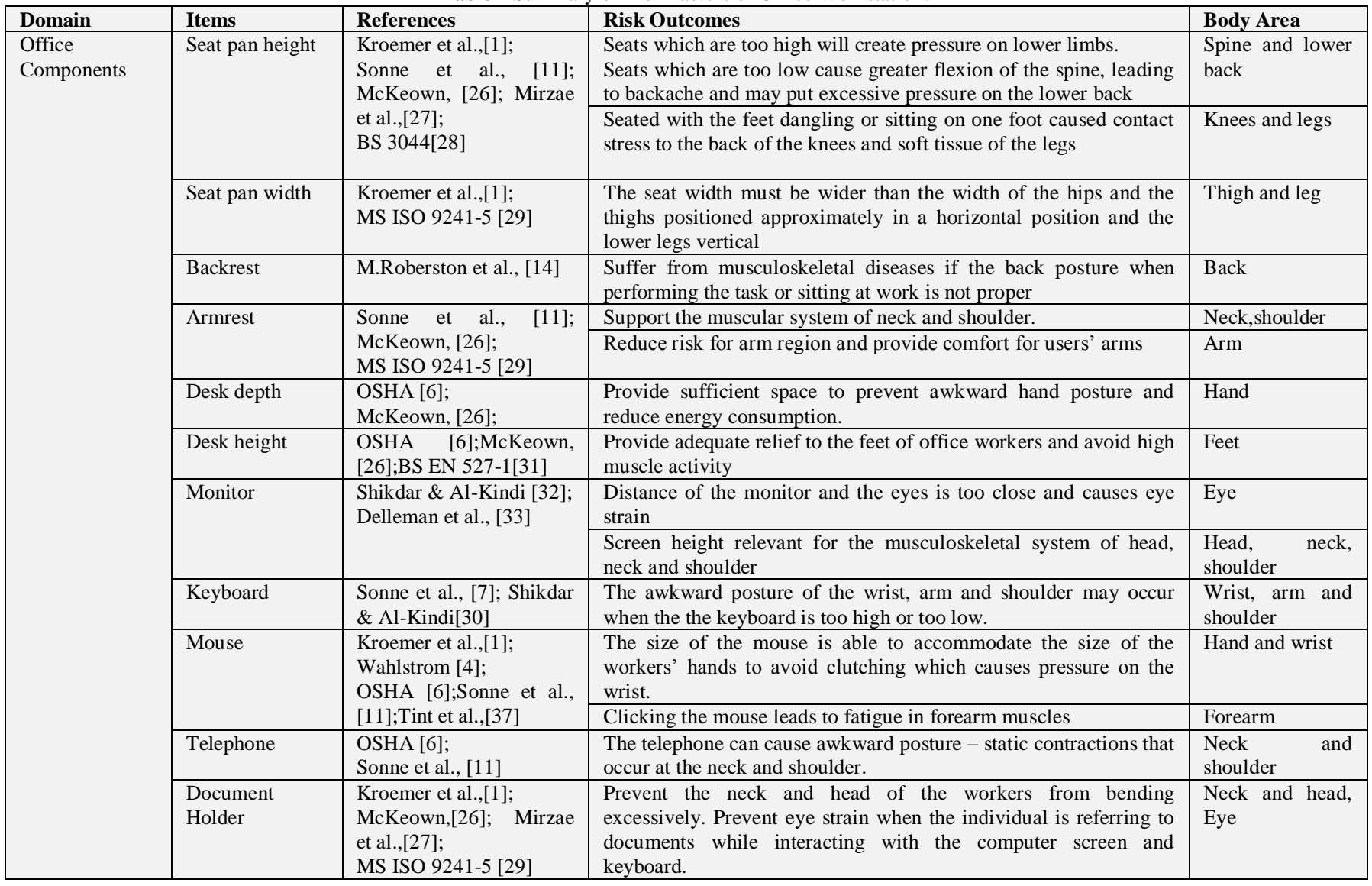




\begin{tabular}{|l|l|l|l|}
\hline \multirow{2}{*}{} & Footrest & $\begin{array}{l}\text { OSHA [6]; } \\
\text { Mirzae et al.,[25]; } \\
\text { MS ISO 9241-5 [27] }\end{array}$ & $\begin{array}{l}\text { Additional support for user's feet when feet do not touch the floor } \\
\text { even when user is in a seated position. }\end{array}$ \\
\cline { 2 - 4 } & Wrist rest & Clifton et al., [3] & $\begin{array}{l}\text { Wrist rest can help maintain a straight wrist posture and reduce } \\
\text { contact stress while typing or clicking mouse. }\end{array}$ \\
\hline $\begin{array}{l}\text { Office } \\
\text { Environment }\end{array}$ & Lighting & McKeown, [26]; & $\begin{array}{l}\text { Illumination or lighting level at the computer workstation must be lower than that } \\
\text { required in an ordinary office. If it is high it may cause glare. }\end{array}$ \\
\cline { 2 - 4 } & Temperature & $\begin{array}{l}\text { Kroemer et al.,[1]; } \\
\text { McKeown, [26] }\end{array}$ & $\begin{array}{l}\text { Temperature can be one of the problems for a computer workstation where the } \\
\text { equipment emits heat. }\end{array}$ \\
\cline { 2 - 4 } & Noise & McKeown, [26] & Reverberation level affects people's perception of how noisy they find their office. \\
\hline
\end{tabular}

From the studies, the workers working with computer for about 6 to $8 \mathrm{~h}$ /day were moderately associated with neck symptoms $(\mathrm{OR}=1.92$, CI:1.21-3.02) and shoulder symptoms $(\mathrm{OR}=1.83$, CI:1.13-2.95) among women and strongly associated with hand symptoms (OR=2.76, CI:1.51-5.06) among men [10]. Studies showed increase in upper body problems occuring among those working for longer hours on a computer [7,9] Besides that, many studies reported increase prevalence of neck and shoulder pain among VDU workers working under improper working conditions such as inadequate lighting, uncomfortable chairs and lack of wrist support [7,12,21,23]. Inappropriate placement of the screen, keyboard, mouse and telephone at workstations, have been associated with musculoskeletal problems [18].

\subsection{Seat Pan / Chair}

From the studies, chairs were found to be associated with musculoskeletal disorders particularly for the upper limb area such as back, shoulder, elbow, hand/wrist and neck $(\mathrm{OR}=1.2-$ $18.40,95 \% \mathrm{CI}=0.6-151.8)[9-10,18-23]$. Besides that, workers who work in a sitting position have a twice the risk neck pain compared to workers who are not always sitting [20]. Therefore, the idea seat height is regarded as a neutral sitting posture where the knees bend about $90^{\circ}$ (feet reach the floor)to avoid MSDs $[11,26,28]$. Besides that, the seat should have sufficient width and depth to support any user or worker comfortably [1]. Lapointe et al.,[22] stated, that white-collared workers are strongly associated with lower back symptoms $(\mathrm{OR}=2.51-5.53$, 95\% CI=1.09-13.03). Therefore, chairs need to have a backrest to support the natural curve of the spine, again with special attention paid to properly support the lumbar region and allow the muscles to relax $[6,29]$. Besides that, the studies found that lower back pain could be caused by the absence of adjustable backrests office chairs [24]. The armrest is part of a good chair design because it can support the muscular system of the neck and shoulders [30]. The ideal armrest allows the elbow to be supported at $90^{\circ}$ where as the shoulders should be in a relaxed position[11,28]

\subsection{Desk}

The surface of the table should provide sufficient space to accommodate office equipment used at a workstation. This prevent a awkward posture and reduces energy consumption [6, 26]. Insufficient working space has been consistently associated with increased risk of symptoms in the elbow-wrist/hand region $(\mathrm{OR}=1.78,95 \% \mathrm{CI}=1.15-2.76)$ [23].

\subsection{Monitor}

The studies show that visual discomfort and musculoskeletal strains, especially in the neck and shoulder area, are associated with computer height $(\mathrm{OR}=1.5,95 \% \mathrm{CI}=0.7-3.1)$ [18]. Therefore, the height of the top line of the display should not be higher than the user's eye level with an angular position of $15^{\circ}$ and $35^{\circ}$ horizontally[26, 29, 30].

\subsection{Keyboard and Mouse}

Jensen et al.,[10] discovered that the keyboard has a strong association with musculoskeletal disorders [OR=2.1] for hands/wrists when workers type for about 6-8 h/day. Typing activity is cited as a risk factor associated with Cumulative Trauma Disorders, neck tension and tendon inflammations[21]. So, a neutral wrist angle should be less than $15^{\circ}$ upward and downward. If wrist is bent more than $15^{\circ}$, it is considered as a wrist bend or flexion [4, 24, 27, 32-34]. Blatter et al., [9] found a slight significant association between mouse use of 6-8 h/day and arm, elbow or wrist/hand disorders $(\mathrm{OR}=1.51$, CI:0.653.53). In addition, location of the mouse is related with the design of keyboard and it may affect the shoulder and arm posture[18]. The mouse should be placed in a suitable position aligned with the users' shoulders and located right next to keyboard (to avoid reach) $[6,11]$.

\subsection{Accessories}

A telephone headset should be provided to avoid static contractions that occur at the neck and shoulders during telephone use $[6,11]$. Document holders should be provided when workers need to refer to documents while interacting with the screen or keyboard[1,26]. Cagnie et al.,[20] stated that, neck pain is significantly associated with neck in a forward bent posture after making the same movement per minute ( $\mathrm{OR}=1.63$, 95\% $\mathrm{CI}=1.02-2.60$ ). Thus, a document holder on the right hand side will minimise the pressure and amount of movement for the neck, head, back and eyes when scanning [27, 29]. Lack of forearm support has been associated with and increase in ulnar deviation of the wrist, also known as risk factor for hand/wrist disorders $(\mathrm{OR}=1.63,95 \% \mathrm{CI}=1.10-2.43)$ [23].Using a wrist rest can maintain a straight wrist posture and reduce contact stress while typing or doing work using the mouse [3]. A footrest should be provided if the user's feet do not touch the floor once they sit ona chair $[6,27]$.

\subsection{Office Environment}

According to Korhonen et al., [18] physical work environment / office environment are positively associated with the outcomes as follows: lighting $(\mathrm{OR}=1.4,95 \% \mathrm{CI} 0.7$ to 2.8$)$, temperature $(\mathrm{OR}=1.2,95 \% \mathrm{CI} 0.6$ to 2.4$)$, and noise condition $(\mathrm{OR}=1.4$, 95\% CI 0.7 to 2.8). Lighting condition are important for the reduction of visual discomfort for VDU work.In addition, poor lighting increases the risk of neck sympyoms among VDU users [23]. The ideal temperature for an office is between $20^{\circ} \mathrm{C}$ to $26^{\circ} \mathrm{C}[1,26,27]$. The sound levels at an office should be kept as low as possible [1]. 


\section{Conclusion}

In summary, the studies show that physical exposure has a moderate to strong association with Computer Work-Related Musculoskeletal Disorder through $95 \%$ Cofidential Interval (CI) and odd ratio (OR) value as shown in Table 1.Through the studies, it was found that computer-related risk factors have a consistent relationship with Musculoskeletal Disorders (MSDs) including awkward postures, long duration of computer use, work involving repetitive processes and the office environment. Besides that, it was found that VDT work resulted in a higher prevalence of disorders in the neck, upper extremities and lower back of the body comparef to non-VDT work

\section{Acknowledgement}

This research is funded by the Ministry of Higher Education of Malaysia (MOHE) and Universiti Tun Hussein Onn Malaysia (UTHM) under the Fundamental Research Grant Scheme (FRGS, Vot 1475)

\section{References}

[1] K. Kroemer, H. Kromer, and K.Kroemer-Elbert, Ergonomics How to design For ease and Efficiency. Prentice Hall International Series in Industrial \& System Engineering, Second Edition, 2001.

[2] Y. Halim, and Z. Taha, Work-Related Musculoskeletal Disorders (WMSDs): An Overview among Malaysian Industrial Employee. International Annual Symposium on Sustainability Science and Management, UTM, Terengganu. Malaysia, 2012.

[3] R. Clifton, M.D. Lacy, E. M. James and G.K. Albert, Cumulative Trauma Disorders in Office Workers. PublicEmployees Occupational Safety and Health Program, 2003.

[4] J. Wahlstrom. Ergonomics, Musculoskeletal Disorders, and Computer Work. Occupational Medicine. Vol 55: 168-176, 2005.

[5] R.J. Graves, K. Way, D. Riley, C. Lawton, \& L. Morris, Development of risk filter and risk assessment worksheets for HSE guidance'Upper Limb Disorders in the Workplace'2002. Applied Ergonomics, 35(5), 475-484, 2004

[6] Occupation Safety \& Health Administration Computer Workstation United State Department of Labor, 2013. Retrived from https://www.osha.gov.

[7] L. Punnet \& U. Bergqvist. Visual display unit work and upper extremity musculoskeletal disorders. Stocholm: National Institute for working Life, 997, 1997.

[8] S.A.. Alazawi. "Prevalence of Musculoskeletal Symptoms among isual Display Terminal Users.” Tirkit Medical Journal 18(1), 127 136, 2012

[9] B.M. Blatter, \& P.M. Bongers, Duration of computer use and mouse use in relation to musculoskeletal disorders of neck or upper limb.International Journal of Industrial Ergonomics, 30(4), 295-306, 2002

[10] C. Jensen, L. Finsen, K. Sogaard, \& H. Christensen, Musculoskeletal symptoms and duration of computer and mouse use.International journal of industrial ergonomics, 30(4), 265-275, 2002.

[11] M. Sonne, D.L. Villalta, \& D.M Andrews, Development and evaluation of an office ergonomic risk checklist: ROSA-Rapid office strain assessment. Applied Ergonomics, 43(1), 98-108, 2012.

[12] J. Village, D. Rempel, K. Teschke, Musculoskeletal disorders of the upper extremity associated with computer work: a systematic review. Occup. Ergon. 5, 205-218, 2005

A. Loghmani, P. Golshiri, A. Zamani, M. Kheirmand, \& N. Jafari, Musculoskeletal symptoms and job satisfaction among officeworkers: A Cross-sectional study from Iran. Acta medica academica, 42(1), 46-54, 2013.

[13] M. Robertson, V.M.Ciriello, \& A.M. Garabet, Office ergonomics training and a sit-stand workstation: Effects on musculoskeletal and visual symptoms and performance of office workers. Applied ergonomics, 44(1), 73-85, 2013.

[14] B.C. Amick III, C.C. Menendez, L. Bazzani, M. Robertson, K. Derango, T. Rooney, A field intervention examining the impact of an ergonomics training and a highly adjustable chair on visual symptoms in a public sector organization. Applied Ergonomics ; 43(3): 625-31, 2012 .
[15]

H. Hemingway, \& M. Marmot, Evidence based cardiology: psychosocial factors in the aetiology and prognosis of coronary heart disease: systematic review of prospective cohort studies. BMJ: British Medical Journal, 318(7196), 1460, 1999.

[16] J. Hartvigsen, S. Lings, C. Leboeuf-Yde, \& L. Bakketeig, Psychosocial factors at work in relation to low back pain and consequences of low back pain; a systematic, critical review of prospective cohort studies. Occupational and environmental medicine, 61(1), 2004.

[17] T. Korhonen, R. Ketola, R. Toivonen, R., Luukkonen, M. Hakkanen, \& E. Viikari-Juntura, Work related and individual predictors for incident neck pain among office employees working with video display units.Occupational and environmental medicine, 60(7), 475482, 2003.

[18] B. Juul-Kristensen, K. Sogaard, J. Stoyer, \& C. Jensen, Computer users' risk factors for developing shoulder, elbow and back symptoms. Scandinavian journal of work, environment \& health, 390398, 2004.

[19] B. Cagnie, L. Danneels, D. Van Tiggelen, V. De Loose, \& D. Cambier, Individual and work related risk factors for neck pain among office workers: a cross sectional study. European Spine Journal, 16(5), 679-686, 2007

[20] N. Turhan, C. Akat, M. Akyuz, \& A. Çakci, Ergonomic risk factors for cumulative trauma disorders in VDU Safety and Ergonomics, 14(4), 417-422, 2008.

[21] J. Lapointe, C.E. Dionne, C. Brisson, \& S. Montreuil, Interaction between postural risk factors and job strain on self-reported musculoskeletal symptoms among users of video display units: a three-year prospective study. Scandinavian journal of work, environment \& health, 134-144, 2009.

A. d'Errico, P. Caputo, U. Falcone, L. Fubini, L. Gilardi, C. Mamo, \& E. Coffano, Risk factors for upper extremity musculoskeletal symptoms among call center employees. Journal of occupational health, $(0)$, 1002160118,2010

[22] C.Y. Cho, Y.S. Hwang, \& R.J. Cherng, Musculoskeletal symptoms and associated risk factors among office workers with high workload computer use. Journal of Manipulative and Physiological therapeutics, 35(7), 534-540, 2012.

[23] T.N. Hanvold, M. Wærsted, A.M. Mengshoel, E. Bjertness, J. Twisk, \& K.B. Veiersted, A longitudinal study on risk factors for neck and shoulder pain among young adults in the transition from technical school to working life. Scand J Work Environ Health, 40(6), 597-609, 2014

[24] C. McKeown, Office ergonomics: practical applications. CRC Press, 2007. R. Mirzaei, S.A.M. Najarkola, B.A. Khanoki, \& H. Ansari, Comparative Assessment of Upper Limbs Musculoskeletal Disorders by Rapid Upper Limb Assessment Among Computer Users of Zahedan Universities, 2014.

[25] BS 3044: Ergonomics principles in the design and selection of office furniture. BSI 389 Chiswick High road London W4 4AL UK, 1990.

[26] MS ISO 9241-5: Ergonomic Requirements for Office work with visual display terminal (VDTs) - Part 5: Workstation layout and postural requirements (ISO 9241-5:1998, IDT), 2005.

[27] ANSI. Chair Checklist and Worksurface Checklist. Cornell University, Dept. Design \& Environment Analysis, Ithaca NY 14850, USA, 2007

[28] BS EN 527-1, Office furniture - work tables and desks. Part 1: Dimension. British Standard Institution, BSI Group Headquarters 399 389 Chiswick High road London W4 4AL UK, 2011.

[29] A.A.Shikdar, \& M.A. Al-Kindi, Office ergonomics: deficiencies in computer workstation design.International Journal of Occupational Safety and Ergonomics, 13(2), 215-223, 2007.

[30] N.J. Delleman, C.M. Haslegrave, \& D.B. Chaffin, (Eds.), Working Postures and Movements. CRC Press, 2004.

[31] S. Hignett, \& L. McAtamney, Rapid entire body assessment (REBA). Applied ergonomics, 31(2), 201-205, 2000.

[32] G. Li, \& P. Buckle, Quick exposure checklist (QEC) for the assessment of workplace risks for work-related musculoskeletal disorders (WMSDs). Handbook of human factors and ergonomics methods, 6-1, 2005.

[33] MS ISO 9241-9, Ergonomic Requirements for Office work with visual display terminal (VDTs) - Part 9: Requirements for nonkeyboard input devices (ISO 9241-9:2000, IDT), 2006.

[34] P. Tint, A. Traumann, V. Pille, V. R. Tuulik-Leisi, \& V. Tuulik, Computer users' health risks caused by the simultaneous influence of inadequate indoor climate and monotonous work.

In AgronomyResearch (Vol. 10, No. Special Issue I, pp. 261-268). Estonian Research Institute of Agriculture, 2012. 
